\title{
Implications of the Use of Sorghum in Broiler Production
}

\section{-Author(s)}

Garcia RG'

Mendes $A A^{2}$

Almeida Paz $\mathrm{ICL}^{1}$

Komiyama $\mathrm{CM}^{3}$

Caldara FR

Nääs $\mid A^{1}$

Mariano WS

Faculdade de Ciências Agrárias Universidade Federal da Grande Dourados (FCA/UFGD), Dourados, MS, Brasil.

2 Faculdade de Medicina Veterinária e Zootecnia (FMVZ/UNESP), Botucatu, SP, Brasil.

3 Faculdade de Ciências Agrárias Universidade Federal da Grande Dourados (FCA/UFGD), Dourados, MS, Brasil.

4 Universidade Federal do Mato Grosso (UFMT), Sinop, MT, Brasil. 3

5 Universidade Federal do Tocantins (UFT) Campus de Araguaína, TO, Brasil.

\section{-Mail Adress}

Corresponding author e-mail address Rodrigo Garófallo Garcia. e-mail: rodrigogarcia@ufgd.edu.br; (67) 3410 2437: Faculdade de Ciências Agrárias, UFGD, Rod. Dourados-Itahum, km 12 CEP 79804-970, Caixa Postal 533. Dourados, MS, Brasil.

\section{-Keywords}

Birds, meat quality, pigments, replacement of corn.

\section{ABSTRACT}

This study aimed at evaluating total or partial replacement of corn by sorghum in broiler diets and at estimating the effect of the pigment supplementation on broiler performance, carcass and cuts yield, and possible breast and leg pigmentation. We used 1680 one-d-old Ross $₫ 308$ broilers. Birds were sexed and distributed according to a completely randomized design $(2 \times 3+1)$. Treatments consisted of a control diet based on corn and diets with two levels corn replacement by sorghum (50 and 100\%) and three pigments levels, with four replicates of 60 birds per treatment. There was no effect $(p>0.05)$ of the dietary replacement of corn by sorghum on performance, carcass and parts yield, and no changes in breast and leg meat $\mathrm{pH}(\mathrm{p}>0.05)$. Meat redness $\left(a^{*}\right)$, yellowness $\left(b^{*}\right)$ and luminosity $\left(L^{*}\right)$ increased $(p<$ 0.05 ) as pigment inclusion levels increased. It was concluded that the use of sorghum instead of corn did not affect broiler performance or carcass and cuts yield. When adequate pigments were used, meat color significantly improved.

\section{INTRODUCTION}

The international increase in feed raw material prices, particularly of corn and soybean, has affected the costs of Brazilian broiler production because feed is the most important variable cost of poultry production. The increasing use of corn for ethanol production in the US has considerably raised corn prices in the international market, directly affecting price dynamics and global poultry production.

Sorghum (Sorghum bicolor L. Moench) is the world's fifth cereal crop, and Brazilian sorghum production is reported to be near 1.9 million tons (Baker et al., 2009). The use of sorghum to replace corn in feeds is economically attractive due to the recent increases in corn prices (Rocha et al., 2008), as mentioned above. However, studies on the replacement of corn by sorghum in broiler diets have yielded controversial results. Sorghum dietary inclusion was associated with worse feed conversion efficiency in broilers (Robertson \& Perez-Maldonado, 2006), while the dietary inclusion of new sorghum cultivars did not affect broiler performance (Garcia et al., 2005a; Rocha et al. 2008).

Carotenoids belong to a group of more 500 pigments, and broilers use these compounds for skin pigmentation and for growth and fertility maintenance (Schiedt, 1998). Variations in fresh meat color are associated with differences in muscle morphology and pH (Fletcher, 2000; Harder et al., 2010). Some meat color defects, such as pale meat, may be due to feed diet and bird stress caused by management practices and poor welfare status (Silva et al., 
2007; Rocha et al., 2008). Meat may also lose its color due to inadequate temperature of storage and further processing (Castro et al., 2008). There are several studies in literature on the inclusion of artificial and natural pigments in poultry feeds that contains sorghum (as this cereal is naturally poor in carotenoids), that report these additives presence do not interfere in poultry performance or meat and egg quality (Sklan et al., 1989; Harder et al., 2010; Moura et al., 2011).

The objective of this study was to evaluate the performance, carcass and cuts yield, and breast and leg meat colorimetry of broilers fed diets containing different sorghum levels in replacement of corn and different carotenoid levels.

\section{MATERIAL AND METHODS}

A total number of 1,680 male Ross $® 380$ chicks was acquired from a commercial hatchery. Birds were distributed according to a completely randomized experimental design in a $(2 \times 3+1)$ factorial arrangement with four replicates of 60 each (Table 1). Broilers were reared in an experimental poultry house and submitted to conventional management.

Corn carotenoid content of the experimental diets was analyzed, and, the calculations for the inclusion of the synthetic pigment were based on that value. The level of carotenoids commonly found in corn is $15 \mathrm{ppm}$. The corn used in this experiment presented a carotenoid content of 18.91 ppm, which is slightly higher than the normal level. The carotenoid content of the sorghum-based diets were was similar to that analyzed for corn.

Sorghum was included according to the following equation: $A \times B=C / 100=D$, where: $A=$ dietary corn percentage; $B=$ corn carotenoid level; $C=$ amount of carotenoids in $100 \mathrm{~kg}$ of feed; and $\mathrm{D}=$ percentage of carotenoids in the diet. This equation was used to determine the amount of sorghum to be included in the diets fed during the three rearing phases. Because the commercial pigment is diluted $(10 \%)$, the level of carotenoids in the diet formulated based on 100\% sorghum was calculated as: $D \times 10=E$, where: $D=$ percentage of carotenoids in the diet and $\mathrm{E}=$ amount of the commercial pigment included in the diet. The amount of synthetic pigment included in each experimental treatment is shown in Table 1.
Table 1 - Dietary synthetic pigment supplementation levels $\left(\mathrm{g}\right.$ ton $\left.^{-1}\right)$ as a function of rearing phase and experimental treatment.

\begin{tabular}{cccccccc}
\hline & \multicolumn{7}{c}{ Treatment } \\
\cline { 2 - 7 } Diet & 1 & 2 & 3 & 4 & 5 & 6 & 7 \\
\hline $\begin{array}{c}\text { Starter } \\
(1-21 \text { days })\end{array}$ & - & - & 53.95 & 80.92 & - & 107.90 & 161.85 \\
\hline $\begin{array}{c}\text { Grower } \\
(22-35 \text { days })\end{array}$ & - & - & 58.29 & 87.43 & - & 116.58 & 174.87 \\
\hline $\begin{array}{c}\text { Finisher } \\
(36-42 \text { days })\end{array}$ & - & - & 63.38 & 95.05 & - & 126.77 & 190.15 \\
\hline
\end{tabular}

$\mathrm{T} 1$ = Control diet with $100 \%$ corn; $\mathrm{T} 2=$ diet with $50 \%$ corn replaced by 50\% sorghum, and no pigment inclusion; $\mathrm{T3}=$ diet with $50 \%$ corn replaced by 50\% sorghum, and 100\% pigment inclusion; T4 = diet with 50\% corn replaced by 50\% sorghum, and $150 \%$ pigment inclusion; $\mathrm{T5}=$ diet with 100\% sorghum, and no pigment inclusion; $\mathrm{T} 6=$ diet with $100 \%$ sorghum, and 100\% pigment inclusion; $\mathrm{T} 7$ = diet with $100 \%$ sorghum, and $150 \%$ pigment inclusion.

The composition of the experimental diets is presented in Table 2. Both water and feed was offered ad libitum during the experimental period. The experimental period was divided in three phases: starter (1 to 21 days), grower (22 to 35 days), and finisher (36 to 42 days). Performance was evaluated at the end of each phase, and included daily weight gain, daily feed intake, feed conversion ratio and mortality.

On day 42, five broilers per replicate were sacrificed to determine carcass yield and deboned breast, thigh, wing, and backs yields; abdominal fat percentage and feed to breast and thigh meat ratio. Carcass yield was calculated as a percentage of live weight. Parts yields were determined as a percentage eviscerated carcass weight. A penetration electrode was introduced directly into the breast and thigh $24 \mathrm{~h}$ postmortem in order to measure $\mathrm{pH}$. This procedure was done for all sampled broilers in order to maintain the meat chilled. Breast muscle and thigh color were assessed with a Hunter ${ }^{\circledR}$ spectrophotometer, using the CIE system. The parameters $L^{*}$ (luminosity), $a^{*}$ (redness) and $b^{*}$ (yellowness) were determined with three replicates, in three different regions, as proposed by Honikel (1998).

Data were statistically analyzed by analysis of variance (ANOVA), using the GLM (General Linear Models) procedure of SAS (SAS, 1998). Means were compared by Tukey's test at 5\% probability level.

\section{RESULTS AND DISCUSSION}

No effect of treatment $(p>0.05)$ was observed at any rearing phase on weight gain (WG), feed intake 
Table 2 - Ingredients and calculated nutritional composition of the experimental diets.

\begin{tabular}{|c|c|c|c|c|c|c|c|c|c|}
\hline \multirow[b]{2}{*}{ Ingredients } & \multicolumn{3}{|c|}{ Starter (1 - 21 days) } & \multicolumn{3}{|c|}{ Grower (22 - 35 days) } & \multicolumn{3}{|c|}{ Finisher (36 - 42 days) } \\
\hline & $\mathrm{M}^{1}$ & $\mathrm{~S} 1^{2}$ & $\mathrm{~S} 2^{3}$ & $\mathrm{M}$ & S1 & S2 & $\mathrm{M}$ & $\mathrm{S} 1$ & S2 \\
\hline & \multicolumn{9}{|c|}{ Composition (\%) } \\
\hline Corn & 57.08 & 28.35 & - & 61.67 & 30.35 & - & 67.00 & 32.76 & - \\
\hline Soybean meal & 36.28 & 35.51 & 34.74 & 30.98 & 31.05 & 30.88 & 26.81 & 27.35 & 25.06 \\
\hline Ground sorghum & - & 28.35 & 57.08 & - & 30.31 & 60.51 & - & 32.76 & 67.16 \\
\hline Soybean oil & 2.97 & 3.70 & 4.40 & 4.00 & 4.61 & 5.23 & 4.28 & 4.98 & 5.84 \\
\hline DL-methionine (99\%) & 0.23 & 0.23 & 0.23 & 0.15 & 0.15 & 0.16 & 0.16 & 0.15 & 0.14 \\
\hline L-lysine & 0.15 & 0.20 & 0.26 & 0.19 & 0.22 & 0.24 & 0.18 & 0.18 & 0.26 \\
\hline Dicalcium phosphate & 1.81 & 1.81 & 1.81 & 1.61 & 1.59 & 1.58 & 0.48 & 0.52 & 0.45 \\
\hline Calcitic limestone & 0.98 & 0.98 & 0.98 & 0.92 & 0.87 & 0.92 & 0.63 & 0.67 & 0.63 \\
\hline Vitamin supplement* & 0.10 & 0.40 & 0.10 & 0.08 & 0.40 & 0.08 & 0.06 & 0.20 & 0.06 \\
\hline Mineral supplement* & 0.05 & 0.12 & 0.05 & 0.05 & 0.10 & 0.05 & 0.05 & 0.08 & 0.05 \\
\hline Salt & 0.35 & 0.35 & 0.35 & 0.35 & 0.35 & 0.35 & 0.35 & 0.35 & 0.35 \\
\hline \multirow[t]{2}{*}{ Total } & 100 & 100 & 100 & 100 & 100 & 100 & 100 & 100 & 100 \\
\hline & \multicolumn{9}{|c|}{ Calculated nutritional composition } \\
\hline Met. energy $\left(\mathrm{kcal} \mathrm{kg}^{-1}\right)$ & 3000 & 3000 & 3000 & 3100 & 3100 & 3100 & 3200 & 3200 & 3200 \\
\hline Crude Protein (\%) & 21.39 & 21.39 & 21.39 & 19.31 & 19.31 & 19.31 & 18.04 & 18.04 & 18.04 \\
\hline Calcium (\%) & 0.96 & 0.96 & 0.96 & 0.87 & 0.87 & 0.87 & 0.80 & 0.80 & 0.80 \\
\hline Available phosphorus (\%) & 0.45 & 0.45 & 0.45 & 0.40 & 0.40 & 0.40 & 0.36 & 0.36 & 0.36 \\
\hline DL- methionine (\%) & 0.49 & 0.49 & 0.49 & 0.45 & 0.45 & 0.45 & 0.41 & 0.41 & 0.41 \\
\hline Methionine + Cystine (\%) & 0.89 & 0.89 & 0.89 & 0.76 & 0.76 & 0.76 & 0.74 & 0.74 & 0.74 \\
\hline Lysine (\%) & 1.26 & 1.26 & 1.26 & 1.15 & 1.15 & 1.15 & 1.04 & 1.04 & 1.04 \\
\hline Tryptophan (\%) & 0.20 & 0.20 & 0.20 & 0.23 & 0.23 & 0.23 & 0.18 & 0.18 & 0.18 \\
\hline Threonine (\%) & 0.79 & 0.79 & 0.79 & 0.75 & 0.75 & 0.75 & 0.63 & 0.63 & 0.63 \\
\hline Potassium (\%) & 0.50 & 0.50 & 0.50 & 0.75 & 0.75 & 0.75 & 0.45 & 0.45 & 0.45 \\
\hline Sodium (\%) & 0.22 & 0.22 & 0.22 & 0.17 & 0.17 & 0.17 & 0.19 & 0.19 & 0.19 \\
\hline Chlorine (\%) & 0.19 & 0.19 & 0.19 & 0.24 & 0.24 & 0.24 & 0.16 & 0.16 & 0.16 \\
\hline
\end{tabular}

'Diet with $100 \%$ corn; ${ }^{2}$ Diet with $50 \%$ corn and $50 \%$ sorghum; ${ }^{3}$ Diet with $100 \%$ sorghum; ${ }^{*}$ Vitamin and mineral supplement; Vitamin supplement (kg of the product): vitamin A 9,000 IU; vitamin B1 - 1,500 mg; vitamin B12- 12 mg; vitamin B2 - 6,000 mg; vitamin B6 - 3,000 mg; vitamin D3 - 2,500 Ul; vitamin E - 20,000 Ul; vitamin K3 - 2,500 mg; Folic acid - 800 mg; Nicotinic acid - 25,000 mg; Pantothenic acid-12,000 mg; Biotin- $60 \mathrm{mg}$. Mineral supplement (kg of the product): Manganese- $160 \mathrm{mg} ; \mid$ ron - $100 \mathrm{mg} ;$ Zinc - $100 \mathrm{mg}$; Copper - 20 mg; Cobalt- 2 mg; lodine - 2 mg; Selenium - 250 mg; Inert material q. s. p.- 1,000 g.

$(\mathrm{Fl})$, feed conversion ratio (FCR), mortality, carcass yield, parts yield, or breast (BMY) and thigh (TMY) meat yield. The dietary replacement of corn by sorghum, with or without pigment inclusion, did not affect feed conversion into breast meat (FCBM) or thigh meat (FCTM) (Table 3). Santos et al. (2006) also did not find any differences in feed intake, weight gain, or feed conversion when evaluating the growth performance of broiler fed sorghum-based diets.

On the other hand, Stringhini et al. (2009) found a quadratic effect on broiler final weight and weight gain, when corn was replaced by sorghum at levels of $21.03 \%$ to $21.68 \%$ compared with the other tested diets with high percentage of addition of sorghum; however, the tested diets did not affect other performance parameters or carcass yield. The results of Robertson \& Perez-Maldonado (2006) showed worse feed conversion ratio when broilers were fed a sorghum-based diet than with corn based diet. On the other hand, in the study of Gualtieri \& Rapaccini (1990), feeding broilers with three levels of corn replacement by sorghum $(0,50$, or $100 \%$ ) had no influence on body weight or carcass and parts weight and yield. Those authors argue that the obtained results are due to the similar nutritional values of corn and sorghum, and therefore, it is possible to formulate diets with close nutritional values, especially for metabolizable energy and amino acids using both sorghum and corn. Although literature results are controversial (Santos, 2006; Rocha et al., 2008; Stringhini et al., 2009), in general, the replacement of corn by sorghum in broiler diets does not compromise performance, as observed in the present study.

Breast and thigh meat color (Table 4) were different $(p<0.05)$ when the pigment was added, as measured by luminosity $\left(L^{*}\right)$, redness $\left(a^{*}\right)$ and yellowness $\left(b^{*}\right)$. $L^{*}$ value decreased $(p<0.05)$ when the pigment was included in the diet, and this decrease was directly proportional to dietary pigment level. 
Table 3 - Weight gain (WG), feed intake (FI), feed conversion ratio (FCR), carcass yield, parts yield, breast meat yield (BMY), thigh meat (TMY) yield, feed conversion into breast meat (FCBM), feed conversion into thigh meat (FCTM) and mortality (\%) of broilers fed diets containing $100 \%$ corn, 50\% corn and 50\% sorghum, or 100\% sorghum and supplemented with different pigment levels between 1 to 42 days of age.

\begin{tabular}{|c|c|c|c|c|c|c|c|c|}
\hline \multirow[t]{2}{*}{ Variable } & \multicolumn{8}{|c|}{ Treatment } \\
\hline & 1 & 2 & 3 & 4 & 5 & 6 & 7 & CV\% \\
\hline WG (g) & 2546 & 2482 & 2505 & 2541 & 2484 & 2505 & 2484 & 6.52 \\
\hline FI (g) & 4763 & 4756 & 4778 & 4757 & 4756 & 4764 & 4784 & 4.84 \\
\hline FCR & 1.89 & 1.96 & 1.91 & 1.88 & 1.94 & 1.93 & 1.90 & 2.12 \\
\hline Carcass yield & 71.43 & 71.29 & 70.71 & 70.81 & 70.68 & 70.51 & 70.48 & 1.39 \\
\hline Thigh yield & 31.34 & 31.65 & 31.90 & 31.11 & 30.73 & 31.21 & 31.91 & 2.85 \\
\hline Wing yield & 11.61 & 11.44 & 11.57 & 11.62 & 11.77 & 11.82 & 11.67 & 3.21 \\
\hline Breast yield & 36.20 & 37.34 & 36.78 & 36.55 & 36.83 & 36.75 & 36.23 & 3.40 \\
\hline Back yield & 20.44 & 20.57 & 20.61 & 21.77 & 21.83 & 21.97 & 21.13 & 4.22 \\
\hline Abdominal fat & 3.37 & 3.91 & 3.14 & 3.20 & 3.39 & 3.40 & 3.59 & 8.67 \\
\hline BMY & 25.75 & 26.89 & 25.93 & 25.11 & 25.27 & 25.31 & 25.47 & 3.58 \\
\hline TMY & 19.67 & 20.74 & 20.81 & 20.91 & 19.04 & 20.11 & 19.24 & 3.36 \\
\hline FCBM & 9.40 & 9.53 & 9.67 & 9.71 & 9.87 & 9.91 & 9.07 & 6.19 \\
\hline FCTM & 12.27 & 12.57 & 12.43 & 12.50 & 12.69 & 12.70 & 12.89 & 6.92 \\
\hline Mortality (\%) & 2.52 & 0.57 & 2.50 & 2.52 & 0.57 & 2.50 & 2.50 & 47.88 \\
\hline
\end{tabular}

$\mathrm{T} 1=$ Control diet with $100 \%$ corn; T2 = diet with 50\% corn replaced by 50\% sorghum, and no pigment inclusion; T3= diet with $50 \%$ corn replaced by $50 \%$ sorghum, and $100 \%$ pigment inclusion; T4 = diet with 50\% corn replaced by 50\% sorghum, and 150\% pigment inclusion; T5 = diet with 100\% sorghum, and no pigment inclusion; $\mathrm{T} 6=$ diet with $100 \%$ sorghum, and 100\% pigment inclusion; $\mathrm{T7}=$ diet with $100 \%$ sorghum, and $150 \%$ pigment inclusion

The effect of corn replacement by sorghum on meat color was observed at both replacement levels. These results are consistent with those of Harder et al. (2010), who observed that broiler' meat luminosity depends on the complement of pigment proportional to its amount. Meat $b^{*}$ value increased with as dietary pigment inclusion increased, and this effect was responsive to increasing to the level of pigment and the two percentages of replacement of corn by sorghum, at both sorghum levels.

The functional properties of meat are primarily dependent on glycolytic reactions that occur during rigor mortis and that directly affect meat $\mathrm{pH}$. Therefore, $\mathrm{pH}$ is an important factor in chicken meat quality assessment. For instance, low meat $\mathrm{pH}$ while meat temperature is still high results in chicken breast meat pale color and reduced water holding capacity (Komiyama et al., 2009). Breast and thigh meat pH was not affected ( $p>0.05$ ) by the substitution of corn by sorghum in the diet, independently of pigment inclusion (Table 4). Breast and thigh meat $\mathrm{pH}$ values were $5.95(C V=2.57 \%)$ and $6.16(C V=2.43 \%)$, respectively. According to Fletcher et al. (2000), the ultimate $\mathrm{pH}$ of normal chicken breast meat ranges between 5.7 and 5.96 and between 6.10 and 6.20 for normal chicken thigh meat. Therefore, the $\mathrm{pH}$ values obtained in the present study can be considered normal.
Meat color is a valuable quality attribute as it is one of the first aspects to be evaluated by consumers on the shelves of supermarkets. Color is an indication of meat freshness and directly influences the consumer's final purchase decision (Garcia, 2005b). Komiyama et al. (2009) tested the relationship between meat color and several other meat quality parameters, such as texture and water retention capacity. The success of a product depends on consumers' acceptance, and its quality and appearance are amongst the most valuable features. When meat quality is assessed, objective criteria such as $\mathrm{pH}$, water holding capacity, tenderness, skin color, and meat color are taken into account. Subjective tests with panels of tasters are performed to estimate meat sensorial characteristics (Komiyama et al., 2009). The causes of variation in fresh meat color are associated with differences in muscle morphology and $\mathrm{pH}$, and some color defects may be caused by preslaughter changes. The most common causes of meat color change are dietary factors, and stress caused by management during rearing to slaughter. Occasionally, meat color loss may also be caused by inadequate meat storage and further processing (Garcia et al., 2005).

The complete replacement of corn by sorghum in broiler diets requires the dietary inclusion of pigments in order to prevent pale chicken meat color. The greatest concern regarding the replacement of corn by 
Table 4 - Breast and thigh meat $L^{*}, a^{*}$ and $b^{*}$ values assessed in two regions (superior and inferior), and $\mathrm{pH}$.

\begin{tabular}{|c|c|c|c|c|c|c|c|c|}
\hline \multirow[b]{2}{*}{ Variable } & \multicolumn{8}{|c|}{ Treatment } \\
\hline & 1 & 2 & 3 & 4 & 5 & 6 & 7 & CV\% \\
\hline \multicolumn{9}{|c|}{ Breast muscle color } \\
\hline$L^{*}$ (superior) & $48.89 \mathrm{~b}$ & $50.46 a$ & $48.72 \mathrm{~b}$ & $47.24 c$ & $52.42 \mathrm{a}$ & $48.96 \mathrm{~b}$ & $47.12 c$ & 14.05 \\
\hline$a^{*}$ (superior) & $3.28 \mathrm{a}$ & $2.15 b$ & $3.17 \mathrm{a}$ & $3.45 \mathrm{a}$ & $2.06 b$ & $3.36 \mathrm{a}$ & $3.56 \mathrm{a}$ & 18.48 \\
\hline b* (superior) & $4.38 \mathrm{a}$ & $3.24 b$ & $4.26 a$ & $4.56 \mathrm{a}$ & $2.98 \mathrm{~b}$ & $4.56 \mathrm{a}$ & $4.65 a$ & 14.69 \\
\hline$L^{*}$ (inferior) & $49.40 \mathrm{~b}$ & $50.29 a$ & $49.26 b$ & $47.12 c$ & $52.01 \mathrm{a}$ & $47.25 c$ & $49.54 b$ & 15.59 \\
\hline$a^{*}$ (inferior) & $3.46 \mathrm{a}$ & $2.18 b$ & $3.21 \mathrm{a}$ & $3.59 a$ & $2.03 b$ & $3.58 \mathrm{a}$ & $3.56 a$ & 14.04 \\
\hline b* (inferior) & $4.50 \mathrm{a}$ & $3.26 b$ & $4.35 \mathrm{a}$ & $4.89 a$ & $3.15 b$ & $4.65 \mathrm{a}$ & $4.88 \mathrm{a}$ & 11.56 \\
\hline \multicolumn{9}{|c|}{ Thigh muscle color } \\
\hline$L^{*}$ (superior) & $47.85 b$ & $49.59 \mathrm{a}$ & $47.49 \mathrm{~b}$ & $46.58 c$ & $51.16 a$ & $47.89 \mathrm{~b}$ & $46.87 \mathrm{c}$ & 16.81 \\
\hline$a^{*}$ (superior) & $8.34 \mathrm{a}$ & $7.32 b$ & $8.21 \mathrm{a}$ & $8.74 a$ & $6.38 c$ & $8.56 a$ & $8.45 a$ & 19.77 \\
\hline b* (superior) & $4.69 a$ & $3.56 b$ & $4.36 \mathrm{a}$ & $4.86 \mathrm{a}$ & $2.28 \mathrm{c}$ & $4.97 \mathrm{a}$ & $4.57 \mathrm{a}$ & 16.83 \\
\hline L* (inferior) & $48.43 \mathrm{~b}$ & $47.26 c$ & $48.32 \mathrm{~b}$ & $46.21 \mathrm{~d}$ & $50.99 a$ & $48.35 b$ & $47.63 c$ & 16.69 \\
\hline$a^{*}$ (inferior) & $8.42 \mathrm{a}$ & $7.34 \mathrm{~b}$ & $8.25 \mathrm{a}$ & $8.54 a$ & $6.14 c$ & $8.72 \mathrm{a}$ & $8.56 \mathrm{a}$ & 13.74 \\
\hline$b^{*}$ (inferior) & $4.91 \mathrm{a}$ & $3.87 \mathrm{~b}$ & $4.58 \mathrm{a}$ & $4.98 \mathrm{a}$ & $2.56 \mathrm{c}$ & $4.99 \mathrm{a}$ & $4.97 \mathrm{a}$ & 12.46 \\
\hline \multicolumn{9}{|l|}{ Breast Meat } \\
\hline $\mathrm{pH}$ & 5.91 & 5.95 & 5.93 & 5.96 & 5.92 & 5.98 & 5.99 & 2.57 \\
\hline \multicolumn{9}{|l|}{ Thigh Meat } \\
\hline $\mathrm{pH}$ & 6.18 & 6.17 & 6.15 & 6.13 & 6.17 & 6.14 & 6.19 & 2.43 \\
\hline
\end{tabular}

Means followed by the same small letters in the same column and in the same row are not different by the test of Tukey ( $p>0.05)$. T1 = Control diet with $100 \%$ corn; $T 2=$ diet with $50 \%$ corn replaced by $50 \%$ sorghum, and no pigment inclusion; $\mathrm{T} 3=$ diet with $50 \%$ corn replaced by $50 \%$ sorghum, and $100 \%$ pigment inclusion; $\mathrm{T} 4=$ diet with $50 \%$ corn replaced by $50 \%$ sorghum, and $150 \%$ pigment inclusion; T5 = diet with 100\% sorghum, and no pigment inclusion; T6 = diet with $100 \%$ sorghum, and $100 \%$ pigment inclusion; $\mathrm{T} 7=$ diet with $100 \%$ sorghum, and $150 \%$ pigment inclusion.

sorghum is related to the absence of carotenoids in sorghum, which may compromise aspects related to meat quality. Carotenoids consist of a group of more than 500 pigments, and birds use these compounds not only for skin and muscle pigmentation, but also to maintain growth and fertility (Schiedt, 1998).

The grain of sorghum is deficient in carotene and xanthophylls, which are responsible for the yellow pigmentation of the egg yolk and the carcass of broiler chickens. Therefore, when substituting corn by sorghum in broiler diets, pigments must be supplemented. The use of sorghum to replace corn in feeds is becoming interesting because of its cost relative to corn. Sorghum costs around 70 to $80 \%$ compared with corn, and it can technically replace up to $100 \%$ corn in broiler diets without affecting bird performance (Rocha et al., 2008).

\section{CONCLUSION}

Sorghum can be used to replace corn in broiler diets. Its use does not affect broiler performance or carcass. Sorghum-based diet reduces chicken meat pigmentation; however, this can be overcome by the addition of synthetic pigments to the feed.

\section{REFERENCES}

Baker A, Allen E, Lutman H. Feed Outlook. USDA Report; 2009.

Castro JBJ, Castillo CJC, Ortega EMM, Pedreira MS. Jejum alimentar na qualidade da carne de frangos de corte criados em sistema Convencional. Ciência Rural 2008; 38: 470-476.

Fletcher DL, Giao M, Smith DP. The relationship of raw broiler breast meat color and $\mathrm{pH}$ to cooked meat color and $\mathrm{pH}$. Poultry Science 2000; 79:784-788.

Garcia RG, Mendes AA, Klink UP, Paz ICL, Takahashi SE, Pelícia K, Komiyama CM, Quinteiro RR. Digestibilidade de rações contendo sorgo com e sem tanino em frangos de corte colostomizados submetidos a três temperaturas ambiente. Ars Veterinaria 2005; 21: 257-264.

Garcia RG, Mendes AM, Costa C, Paz ICLA, Takahashi SE, Pelícia K, Komiyama CM, Quinteiro RR. Desempenho e qualidade da carne de frangos de corte alimentados com diferentes níveis de sorgo em substituição ao milho. Arquivo Brasileiro de Medicina Veterinária e Zootecnia 2005; 57: 634-643

Gualtieri M, Rapaccini S. Sorghum grain in poultry feeding. World's Poultry Science Journal1999; 46: 246-254.

Harder MNC, Spada FP, Savino VJM, Coelho AAD, Correr E, Martins E. Coloração de cortes cozidos de frangos alimentados com urucum. Ciência e Tecnologia de Alimentos 2010; 30: 507-509.

Honikel KO. Reference methods for the assessment of physical characteristics of meat. Meat Science 1998; 49: 447-457.

Komiyama CM, Mendes AA, Takahashi SE, Moreira J, Borba HBA, Leonel FR, Roça RO, Almeida ICLA, Neto AB. Características qualitativas de 
produtos elaborados com carne de frango pálida e normal. Ciência e Tecnologia de Alimentos 2009; 29: 38-45.

Moura AMA, Takata FN, Nascimento GR, Silva AF, Melo TV, Cecon PR. Pigmentantes naturais em rações à base de sorgo para codornas japonesas em postura. Revista Brasileira de Zootecnia 2011; 40: 24432449.

Robertson SK, Perez-Maldonado RA. Nutritional characteristics of sorghums from QSL and MSW. Zootecnica International 2010; 32: 38-43.

Rocha VRRA, Junior WMD, Rabello CBV, Ramalho RP, Ludke MCMM, Silva EC. Substituição total do milho por sorgo e óleo de abatedouro avícola em dietas para frangos de corte. Revista Brasileira de Zootecnia2008; 37: $95-102$

Santos MSV, Espíndola GB, Fuentes MFF, Freitas ER, Carvalho LE. Utilização de complexo enzimático em dietas à base de sorgo-soja para frangos de corte. Revista Brasileira de Zootecnia 2006; 35: 811-817.
SAS Institute, SAS User's Guide. SAS Institute Inc., Cary, NC, 1998.

Schiedt K. Absortion and metabolism of carotenoids in birds, fish and crustaceans. Biosynthesis and Metabolism of the carotenoids. Birkhauser 1998; 3: 285-358.

Silva MAN, Filho JADB, Silva CJM, Rosário MF, Silva IJO, Coelho AAD, Savino VJM. Avaliação do estresse térmico em condição simulada de transporte de frangos de corte. Revista Brasileira de Zootecnia 2007; 36: $1126-1130$

Sklan D, Yosefov T, Friedman A. The effects of vitamin A, $\beta$-carotene and canthaxanthin on vitamin A metabolism and immune response in the chick. International Journal of Vitamin Nutrition 1989; 59: 245-249.

Stringhini JB, Arantes UM, Laboissière M, Cunha MIR, Pedroso AA, Leandro NSM. Desempenho de frangos de corte consumindo rações contendo sorgo e gérmen integral de milho. Revista Brasileira de Zootecnia 2009; 38: 2435-2441. 